\title{
Linguistic analysis of the peculiarities of the French-language legal task texts
}

\author{
Ivan I. Sinyakin - Ekaterina A. Samorodova - Irina G. Belyaeva
}

DOI: 10.18355/XL.2020.13.02.02

\begin{abstract}
Juridical linguistics is a particular branch of linguistics which studies the linguistic aspects of interaction between language and law. This research is devoted to the analysis of linguistic peculiarities of legal task texts in French, as well as to some other aspects of juridical linguistics. Legal tasks in a foreign language are a crucial component of the language material used in professionally-oriented training of international lawyers, representing a particular category of legal texts, including the characteristics of normative texts and the texts of judicial decisions, but having a sort of emotional colouring which differentiates it from other types of legal documents.

The authors of the present research have managed to carry out a holistic grammatical, lexical and syntactic analysis of the legal task texts, to reveal the peculiarities of the text structure and to establish the basic principles of creating a legal task text in the French language.
\end{abstract}

Key words: linguistic analysis, linguistic peculiarities, text structure, juridical linguistics, case studies, legal task, professional discourse, international law

\section{Introduction}

Language and law have been inextricably linked for a long time. The interrelation and interaction between language and law, as well as the linguistic aspects of law represent the object of study for a relatively new interdisciplinary science - juridical linguistics, which appeared at the end of the 20th century. The field of juridical linguistics also includes studying the patterns of natural language, which form the basis of the legal text, and in many respects, determine both its creation and its use in legal practice.

A legal task in the context of this research is considered as a particular type of a legal text, combining the characteristics of various kinds of legal documents and representing an interesting subject for linguistic analysis and for juridical linguistics in general.

The purpose of this article is to analyze the linguistic peculiarities of foreign-language legal task texts which are used in classes specialist French language classes for international lawyers.

The topicality of this research is best explained by the necessity to analyze the grammatical, lexical, syntactic content of French-language legal educational tasks texts in detail, to identify the linguistic peculiarities of legal task texts of various types and language levels for these texts to be correctly written in the future.

The present research attempts to find a solution to the following issues:

- to determine the most common typological variety of the legal task texts;

- to determine the lexical, grammatical, syntactic and stylistic specifics of the typical language constructions in the legal task texts;

- to establish how the legal task texts correspond to the general characteristics of the legal text.

The main methods used during the current research were comparative method, contrastive method, system analysis method.

XLinguae, Volume 13 Issue 2, April 2020, ISSN 1337-8384, ISSN 2453-711X 
The subject of the study is presented by those linguistic, grammatical, and stylistic peculiarities of legal task texts as a particular type of legal documents, which are used in teaching the French language of the international law to students learning French as the first or the second foreign language.

\section{Literature review}

Despite the fact that juridical linguistics, which studies the functioning of a language in law, is a relatively new branch of linguistics, the interaction of language and law has been the subject of research for many years. A significant contribution - about 40 scientific works - to the study of the linguistic aspects of legal texts, their typology, the semantics of legal concepts and documents, the statutory language as a specialist language, was made by Dietrich Busse, for example: (Busse, 1991), (Busse, 1992a), (Busse, 1992b), (Busse, 1993), (Busse, 2000a), (Busse, 2000b), (Busse, 2005), (Busse, 2018a), (Busse, 2018b), (Busse, 2019). The typology of legal texts (Engberg, 1993), their translation (Prieto, 2011), the role of particles (Leung John, 2009), legal terminology (Alwazna, 2018), the functions of interrogative sentences (Sala, 2019), lexemes (Irkova, 2019) have been studied as well. Linguists have been addressing to the studies of the language of legal processes (Levi, 1990), the characteristics and functions of the statutory language (Charrow, Crandall, Charrow, 1982), the analysis of legal texts (Auer, Berteloot, Mielke, Schikora, Schmidt, Wolff, 2019), court documents (Yao, Ge, Li, Yao, Li, Zeng, Chang, 2019), the jury language (Johansen, 2018). Computer-assisted legal linguistics (Vogel, Hamann, Gauer, 2018) has become a separate branch of linguistics.

Professional discourse in the framework of the current article is studied as verbal communication, based on the theoretical and practical knowledge necessary for professional activity in order to solve a professional task (in this case, legal.)

Case study (Brattseva, Kovalev, 2015) is a method which fully implements the legal task in the process of professional training of international students, within the framework of the competency-based approach, which has established itself as the most effective one for 148 years (Garvin, 2003), allowing to bring the training closer to real professional discourse.

In various studies, the concept of a case study is interpreted differently. Sometimes a case study is considered as a passive activity, which serves as an example to demonstrate the solution of a legal situation to a student (Moskovitz, 1992: 246). In this case, we can point out the distinction between the concepts of case-method and method-problem methods: "While the case-method shows the student how others solve problems, method-problem allows students to learn how to solve problems on their own" (Moskovitz, 1992: 246).

With regard to professionally-oriented training, the effectiveness of the problem method, which finds itself outside the framework of the case study, is proved in scientific works by Wilfried Admiraal, Theo Wubbels, Albert Pilot (Admiraal, Wubbels, Pilot, 1999); Myron Moskovitz (Moskovitz, 1992); Philippa Ryan (Philippa, 2017). In other studies, case studies are considered in a broader sense as a method that allows students to independently find effective solutions to problems that they may encounter in similar real professional situations (Cakmak, Akgün, 2017). Case studies can combine the elements of such methods as gaming (imitation of professional situations), problem-search (acquisition of knowledge by resolving problematic situations), cooperative training (collective interaction to solve a problem), scenariosituational (modeling standard professional situations), heuristic (researching a question by reasoning), discussion (discussing a problem), brainstorming (finding a solution by putting forward various options), CLIL (development of language skills through interdisciplinary relations). 
The success of case studies is determined by its correlation with practical professional activity, and the increased number of methods which have now become its components contributes to the training of highly qualified professionals who are able to independently solve the problems posed to them by their profession. This explains the continuous improvement of the case method as a result of its application in the framework of new modern methods and its leading position among the most effective teaching methods not only for lawyers, but also for specialists in various fields.

The case method is based on a legal task. A legal task, in turn, is a legal text.

Whereas a legal task in legitimate science is considered as a problematic situation created by certain circumstances which demand the use of lawful means to immediately solve the problem (Zhalinskij, 2009), then in the context of linguistic analysis a legal task stands for a statutory text created for educational purposes in accordance with the teaching aim, Such text has its own linguistic peculiarities at grammatical, lexical, terminological, semantic and syntactic levels.

\section{Materials and methods}

The texts of legal tasks are legal texts which can be the subject of research as a source of law and as a particular text demonstrating the characteristic peculiarities of using lexical, morphological and syntactic language means. Despite the significant differences between law and linguistics, between studying legal documents and fulfilling legal tasks, these areas of knowledge are not mutually exclusive. As we have already mentioned in this research, the basis of juridical linguistics is represented by combination, interaction and mutual influence of language and law.

This interconnection especially affects the implementation of law and its functioning, because the creation of a legal text is a language problem. In order to understand what types of legal text are included in a document of a legal task, we should address relevant studies.

Juridical linguistics commonly classifies legal texts according to the areas of legal activity in which these texts are created and used. According to this principle, there are reasons to highlight law-making or law constituting texts (texts of the charters, conventions, treaties, resolutions), administrative texts (circular notes, ordinances, departmental and subordinate documents, correspondence, business letters, notifications, announcements) and legal texts related to the administration of justice (court decisions, opinions, complaints, lawsuits (Eriksen, 1999).

Regarding the logical nature and structure of the legal text, S. Sarcevic (Sarcevic, 1997) proposed a criterion of descriptivity and prescriptivity. A prescriptive legal text prescribes, and a descriptive text describes. Correspondingly, three types of legal text can be distinguished:

- Prescriptive - i.e. texts of laws, decisions, decrees

- Descriptive - i.e. doctrinal texts, scientific research

- Mixed type - i.e. texts combining the characteristics of the two previous types (lawsuits, circular notes, directives)

The German researcher V. Otto proposed a special structure of the legal language, according to which the structure of legal texts is based on the peculiarities of the language content, accuracy, conciseness of terms. Thus, there exist the following types of the legal language:

1. the language of laws (treaties, conventions, pacts, or documents containing the rule of law);

2. the language of judicial decisions (court decrees, comments)

3 . the language of legal science and expert examinations (scientific research in the field of law, scientific comments, discussion of special legal issues between specialists);

XLinguae, Volume 13 Issue 2, April 2020, ISSN 1337-8384, ISSN 2453-711X 
4. the language of departments;

5. administrative jargon (informal discussion of legal matters between specialists) (Otto, 1981).

According to another European researcher, T. Gizbert-Studnicki, there exist: 1) the texts of regulatory legal acts; 2) the writings of judicial decisions; 3 ) the texts of legal doctrine; 4) the texts formulated in the process of implementing broadly understood legal activities (legal customs) (Gizbert-Studnicki, 1986: 139). In addition, the researcher allowed the possibility of dividing these groups into subgroups, since the main criterion is the legal context: to whom the statutory text is addressed, what it is aimed at (Gizbert-Studnicki, 1986).

The documents of legal tasks are unique since they combine the characteristics of all types of legal texts and include the distinguishing special features, thus presenting an interesting subject for study.

Therefore, the main components of the legal text are:

- Lack of expression

- Coherence and consistency

- Accuracy, clarity, and conciseness

- Simplicity of presentation

- Use of terminology

If we are not implying the text of a lawyer's speech during the defense of the accused, the legal text is remarked and valued for its neutrality, impartiality, emotional "coldness," and lack of any originality. Normative texts are not characterized by "splendor of phrases" and eloquence; sentences are to be non-exclamatory and narrative in the nature and type of utterance. In other words, the even tone of the text should not provoke any emotions and associations.

The coherence and consistency of the constituent parts of a legal text compose its basic requirement and its most essential features. A break in thoughts, incomplete phrases, inconsistent presentation of facts, and materials are unacceptable, since the result, the use of such text in legal practice is directly dependent on these text parameters.

The accuracy and clarity of the legal text make up the irrefutable evidence of its reliability.

Here, linguistic content plays an important role. The correctness of the terms used, the compatibility of words and expressions in the text provide semantic unity and, thus, effective use in the regulation of particular relations.

The legal text is characterized by its linguistic standardization. The use of common and fixed phrases, which are inherent to the statutory language, standardized phrases and clichés give a unique stylistic charm to the legal jargon. Creating a legal text, its author must remember that its further application depends on its accuracy. It should also be taken into account that a legal text is to be understandable and straightforward. Long and sophisticated phrases, the use of complex grammatical tenses and constructions complicate its perception and lead to an incorrect interpretation of its content.

One of the key characteristics of a legal text is the use of terms as the primary lexical means of expressing the normative content of the right. As an example, we may consider the following terms in French: Droit aérien (air law), Droit de l'Espace (space law), Droit privé (private law), succession (succession), traité (an international treaty), reconnaissance (recognition). The legal language is also characterized by the polysemy of terms; when the same term can be used to denote several concepts. In this case, there is a need in clarifications. The person interpreting the contract must clearly understand what the legislator intended to say. In addition, legal vocabulary includes a large number of words which, apart from legal texts, are used in ordinary language. 
For example:

- Personne - Individual - a person

- Succession - Succession - Inheritance

- Devoir - Debt - homework

- Siège - Headquarters - apartment - armchair

Legal texts present a very interesting subject in terms of their compositional structure. The texts of normative acts are divided into sections, parts, chapters, and paragraphs. International conventions and treaties include the preamble, the main body, and annexes.

Judicial decisions and judicial acts, particularly the decisions of the UN Court, represent a particular type of legal documents and require a more detailed study.

The text of judicial decisions consists of several parts: the first part of the text is usually descriptive and devoted to the accurate and complete presentation of the facts of the case. The second, operative, the part is descriptive and contains imperative forms.

As to the lexical content, the texts of judicial decisions are characterized by dry language, lacking expressiveness. The text is dominated by bureaucratic language, which does not occur out of context (plaintiff - demandeur, defendant - défendeur). The style is full of standard phrases, clichéd expressions, e. g:

- dans le cas contraire - otherwise

- à l'expiration de - upon the expiry of

- s'il n'en convient autrement - unless agreed otherwise

- en conformité de - pursuant to

- $\quad$ sous réserve de - subject to

- en vertu de la loi - under the law

Personal pronouns are not used in the texts of court decisions; the actors of the facts are named according to their status or by name. (Ms. Durois, plaintiff, - Mme Duroy, demandeur).

The text of court decisions also recognizes predominating impersonal forms of verbs (it must be noted - (passive voice - il est à noter, il est à decider etc.). This, to some extent, expresses the philosophy of international law, since impersonal forms convey the predominance of the will of the state, not of an individual.

The syntax of a judicial decision is rich in lengthy and complex sentences. This can be explained by the intention to fully reflect the necessary information without losing a single fact and by the need for brevity.

\title{
Research results
}

As we have mentioned above, the texts of legal tasks are also legal texts and have identical characteristics, as well as their own stylistic, grammatical, semantic features. In terms of content, the texts of legal tasks most often resemble the texts of judicial decisions in their structure, since the authors of the texts of legal tasks are guided by the practice of international courts and tribunals in order to create a current legal situation.

As an example of this research, we may analyze the option of extracting a legal task prepared by the Leiden Institute of International Air and Space Law for the international competition in air law.

\author{
DE SAISINE DE LA COUR INTERNATIONALE DE JUSTICE, \\ AU SUJET DU DIFFÉREND ENTRE LA RÉPUBLIQUE DU CARPANIA \\ ET LE ROYAUME DE GONDOUR RELATIF À L'USAGE DE LA \\ FORCE CONTRE LE VOL HHP 1234
}

XLinguae, Volume 13 Issue 2, April 2020, ISSN 1337-8384, ISSN 2453-711X 


\begin{tabular}{l}
\hline INTRODUCTION \\
\hline 1. Carpania is a tranquil island in the far \\
reaches of the Turquoise Ocean. It is poor \\
but beautiful. The mainstay of its \\
economy is agriculture, but it has recently \\
become the 'go to' destination for rich \\
tourists and has built several 5 star resorts \\
that are always full to overflowing. \\
2.Carpania's nearest neighbour is \\
Gondour, a large State stretching along \\
the coast of the continental land mass \\
some 100km away from the territorial \\
border of Carpania There is one airway \\
established under the Reginal Air \\
Navigation Plan that connects Carpania to \\
the wider world, Airway 666. It runs \\
across Gondour's airspace, crossing its \\
coast near the Pom-Pom nature \\
reservation.
\end{tabular}

3. Gondour is a rich industrial country, but does not attract as much tourism as Carpania. Although it does have some tourist resorts, they are less developed than those of Carpania and have increasingly lost custom to them. As reported by national newspapers, "this has hurt Gondour national pride greatly, much to the anger of its King, Miguel III."

4. As a rich State, Gondour has been able to equip its one airline, GonAir, with the latest fuel- efficient electric jet aircraft known as the Electra 230. The Electra 230 has a maximum take off mass (MTOM) of $56,000 \mathrm{~kg}$ and is certified to Chapter 4 of Part II of Volume I of Annex 16 to the Chicago Convention.

5. In contrast, as a poor State Carpania's one airline, Carpa Airline, continues to use gas- guzzling propeller driven aircraft, known as the Conquest 4, that were first acquired in the 1950s and registered in Carpania ever since, that is, since 22 June 1956. In 2005, the aircraft

\section{INTRODUCTION}

1.Carpania est une île tranquille située dans l'océan Turquoise. C'est assez pauvre pauvre mais beau. Le pilier de son économie est l'agriculture, mais elle est récemment devenue la destination incontournable des touristes riches et a construit plusieurs complexes hôteliers 5 étoiles toujours pleins à déborder.

2. Le voisin le plus proche de Carpania est Gondour, un grand État qui s'étend le long de la côte de la masse continentale à une centaine de kilomètres de la frontière territoriale de Carpania. Il y a une voie aérienne établie dans le cadre du Plan de navigation aérienne Regional qui relie Carpania au monde plus large, la voie aérienne 666. Elle traverse l'espace aérien de Gondour, traversant sa côte près de la réserve naturelle de Pom-Pom.

3. Gondour est un pays industriel riche, mais n'attire pas autant le tourisme que Carpania. Bien qu'elle possède quelques stations touristiques, elles sont moins développées que celles de Carpania et ont de plus en plus perdu leur habitude. Comme le rapportent les journaux nationaux, «cela a considérablement nui à la fierté nationale de Gondour, à la grande colère de son roi, Miguel III»).

4. En tant qu'État riche, Gondour a été en mesure d'équiper sa seule compagnie aérienne, GonAir, du dernier avion à réaction électrique à faible consommation de carburant connu sous le nom d'Electra 230. L'Electra 230 a une masse maximale au décollage (MTOM) de $56000 \mathrm{~kg}$ et est certifié conforme au chapitre 4 de la partie II du volume I de l'annexe 16 de la convention de Chicago.

5. En revanche, en tant que seule compagnie aérienne d'un État pauvre de Carpania, CarpaAirline, continue d'utiliser des appareils à hélice à essence, connus sous le nom de Conquest 4 , qui ont été acquis pour la première fois dans 
owned and operated by Carpa Airline were modified to improve their performance and reduce the noise from their propeller engines. The modifications allowed the aircraft to meet the requirements laid down in Chapter 3 of Part II of Volume I of Annex 16 to the Chicago Convention on Environmental Protection. On 22 December 2006, the competent civil aviation authorities of Carpania have re- certificated the Conquest 4 aircraft owned by Carpa Airlines to Chapter 3 of Annex 16. The Conquest 4 has a maximum certificated take-off mass of $34,670 \mathrm{~kg}$. les années 50 et enregistrés en Carpanie depuis, c'est-à-dire depuis 22 juin 1956. En 2005, les avions détenus et exploités par CarpaAirline ont été modifiés pour améliorer leurs performances et réduire le bruit de leurs moteurs à hélices. Les modifications ont permis à l'aéronef de satisfaire aux exigences énoncées au chapitre 3 de la partie II du volume I de l'annexe 16 de la convention de Chicago sur la protection de l'environnement. Le 22 décembre 2006, les autorités compétentes de l'aviation civile de Carpania ont recertifié l'avion Conquest 4 appartenant à Carpa Airlines au chapitre 3 de l'annexe 16. Le Conquest 4 a une masse maximale certifiée au décollage de $34670 \mathrm{~kg}$

\section{BACKGROUND}

7. On 25 March 2018, a pair of Dodo birds was allegedly found nesting in Gondour's Pom- Pom nature reserve by a scientist from its Nature Institute, Dr Doolittle, although he was not able to capture them on camera. This caused great excitement as the species had previously been thought to be extinct.

8. On 1 April 2018, Gondour's Parliament passed into force the Dodo Act 2018, one of the provisions of which was that in order to preserve the Dodo: (1) aircraft may only fly on Airway 666 between Gondu City and the end of Gondour's territorial waters in the Turquoise Ocean if:

1. (a) they are powered by electric motors; and

2. (b) they fly on that route at a height of no less than 20,000 feet above ground level (agl); and

(2) any aircraft not meeting these requirements wishing to fly between Gondu City and the end of Gondour's territorial waters in the Turquoise Ocean must use a new route, Airway 777 as established in accordance with ICAO Annex 11 on Air Traffic Serviced, the Procedures for Air

\section{CONTEXTE}

7. Le 25 mars 2018, une paire d'oiseaux Dodo aurait été trouvée en train de nicher dans la réserve naturelle de GondourPom-Pom par un scientifique de son Institut de la nature, le Dr Doolittle, bien qu'il n'ait pas pu les capturer à la caméra. Cela a provoqué une grande excitation car l'espèce était auparavant considérée comme éteinte.

8. Le 1er avril 2018, est entré en vigueur la loi de 2018 sur le Dodo adoptée par le Parlement de Gondour, dont l'une des dispositions était celle visant à préserver le Dodo:1) les aéronefs ne peuvent voler sur la voie aérienne 666 entre la ville de Gondu et la fin des eaux territoriales de Gondour dans l'océan Turquoise que si:

a) ils sont alimentés par des moteurs électriques; et

b) ils volent sur cette route à une hauteur d'au moins 20000 pieds audessus du sol (agl); et

(2) tout aéronef ne répondant pas à ces exigences souhaitant voler entre la

XLinguae, Volume 13 Issue 2, April 2020, ISSN 1337-8384, ISSN 2453-711X 


\begin{tabular}{|c|c|}
\hline $\begin{array}{l}\text { Navigation Services (PANS) on Air Traffic } \\
\text { Management, and the applicable Regional } \\
\text { Air Navigation Plan. } \\
\text { (3) Any aircraft flying below a level of } 5000 \\
\text { feet agl, and/or using an airport on the } \\
\text { territory of Gondour, must meet the } \\
\text { certification requirements of Chapter } 4 \text { of } \\
\text { Part II of Volume I of Annex } 16 \text { to the } \\
\text { Chicago Convention. }\end{array}$ & $\begin{array}{l}\text { ville de Gondu et la fin des eaux } \\
\text { territoriales de Gondour dans l'océan } \\
\text { Turquoise doit emprunter une nouvelle } \\
\text { route, la voie aérienne } 777 \text {, établie } \\
\text { conformément à l'annexe } 11 \text { de } \\
\text { l'OACI sur le trafic aérien desservi, les } \\
\text { procédures de Services de navigation } \\
\text { aérienne (PANS) sur la gestion du } \\
\text { trafic aérien et le plan régional de } \\
\text { navigation aérienne applicable. } \\
\text { (3) Tout aéronef volant au-dessous } \\
\text { d'un niveau de } 5000 \text { pieds agl et / ou } \\
\text { utilisant un aéroport sur le territoire de } \\
\text { Gondour, doit satisfaire aux exigences } \\
\text { de certification du chapitre } 4 \text { de la } \\
\text { partie II du volume I de l'annexe } 16 \text { de } \\
\text { la convention de Chicago. }\end{array}$ \\
\hline STATEMENT OF FACTS & LES FAITS \\
\hline RELIEF SOUGHT & DECISION DEMANDÉ \\
\hline
\end{tabular}

In the research, we have presented only several aspects of this legal task. The task is arranged according to the scheme and structure of the suit filed to the UN Court. The text complies with all the syntactic rules for creating a similar type of legal texts. The text is divided into two parts: descriptive and prescriptive (operative).

The results of the syntactical analysis of the text of this task can be presented in the following table 1 and figure 1 .

\begin{tabular}{|c|c|c|}
\hline Task text & Result in \% & Example \\
\hline Simple sentences & 15 & $\begin{array}{l}\text { Carpania est une île tranquille } \\
\text { située dans l'océan Turquoise. }\end{array}$ \\
\hline Complex sentences & 85 & $\begin{array}{l}\text { En revanche, en tant que seule } \\
\text { compagnie aérienne d'un État } \\
\text { pauvre de Carpania, } \\
\text { CarpaAirline, continue } \\
\text { d'utiliser des appareils à hélice } \\
\text { à essence, connus sous le nom } \\
\text { de Conquest 4, qui ont été } \\
\text { acquis pour la première fois } \\
\text { dans les années } 50 \text { et } \\
\text { enregistrés en Carpanie } \\
\text { depuis, c'est-à-dire depuis } 22 \\
\text { juin } 1956 \text {. }\end{array}$ \\
\hline
\end{tabular}


Arrangement in parts, + paragraphs and subparagraphs

Table 1: The structure and syntax of the legal task text

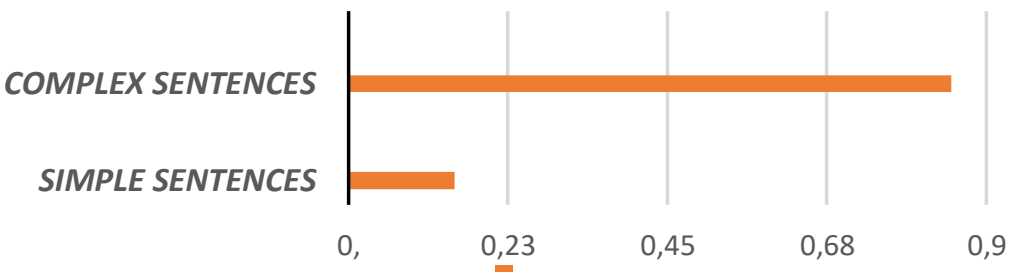

Figure 1: The structure and syntax of the legal task text

Figure 1 shows the number of simple and complex sentences in the text of the legal task in percent.

The lexical and grammatical features of the text and the use of terminology are presented in percent in Table 2 .

\begin{tabular}{|l|l|l|}
\hline & Result in \% & Example \\
\hline Terms & 20(100) & $\begin{array}{l}\text { Annexe } \\
\text { certificat } \\
\text { loi } \\
\text { aéronef }\end{array}$ \\
\hline Cliché and fixed phrases & $27(100)$ & $\begin{array}{l}\text { Entre en viguer } \\
\text { En conformité de } \\
\text { Loi en tant que telle }\end{array}$ \\
\hline Impersonal Constructions & 30 & $\begin{array}{l}\text { Il est procédé } \\
\text { Il est à noter } \\
\text { Il est défini }\end{array}$ \\
\hline Passive voice & 23 & $\begin{array}{l}\text { Ont été } \\
\text { acquis(documents) } \\
\text { A été adoptée (loi) }\end{array}$ \\
\hline & & \\
\hline
\end{tabular}

Table 2: Lexical and grammatical features of the legal task text 


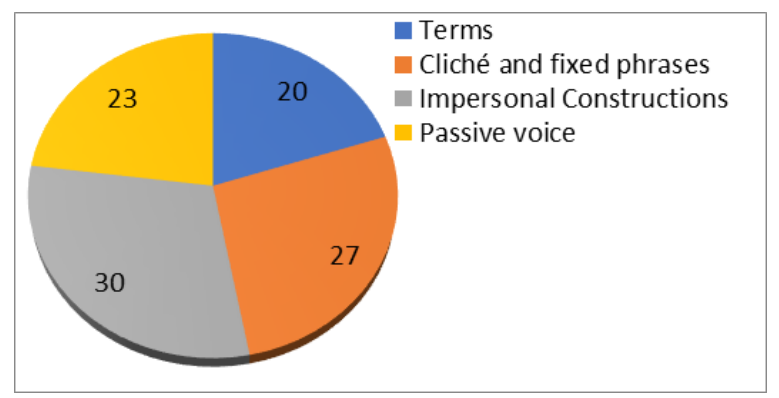

\section{Figure 2: Lexical and grammatical features of the legal task text}

Figure 2 demonstrates the harmonious interaction between various lexical and grammatical structures of the text. Impersonal constructions and fixed phrases prevail, which is typical of a legal text.

The total volume of terms does not make up more than $20 \%$ of the text. This makes the text of this legal task easily understandable.

In order to conduct a comprehensive analysis of the linguistic peculiarities of the legal task text, we have studied 250 legal task texts presenting various types of legal tasks - research, search, evaluation, and correction - belonging to different branches of international law: air law, the law of the sea, space law, environmental law, nuclear law, commercial law, criminal law, as well as private law.

The research has shown that all types are characterized by the features of a legal, regulatory text, such as

- Coherence and consistency

- Accuracy, clarity, and conciseness

- Simplicity of presentation

- The use of industrial terminology

- Corresponding syntactical structure

The linguistic analysis of the texts of legal tasks has demonstrated an equal presence of impersonal constructions and passive voice, terms, fixed phrases.

The content of the texts of legal tasks in its structure, syntax, and lexical content includes the features of judicial acts: judicial decisions, orders, lawsuits, as well as the elements of normative acts (treaties, conventions) and doctrinal research.

The results of the research are presented in table 3 .

The types of legal task texts $100 \%$

\begin{tabular}{|c|l|l|l|}
\hline $\begin{array}{c}\text { Branch of law } \\
\text { (250 texts) }\end{array}$ & Mixed type & Descriptive & Prescriptive \\
\hline 1. Air law (35) & 20 & 10 & 5 \\
\hline $\begin{array}{c}\text { The law of the sea } \\
(45)\end{array}$ & 30 & 15 & 10 \\
\hline 3. Space law (30) & 15 & 10 & 5 \\
\hline
\end{tabular}




\begin{tabular}{|cl|l|l|l|}
\hline 4. & Economic law (25) & 10 & 10 & 5 \\
\hline $\begin{array}{l}\text { 5. } \begin{array}{l}\text { Environmental } \\
\text { law(50) }\end{array} \\
\text { 6. }\end{array} \quad \begin{array}{l}\text { Commercial law } \\
(30)\end{array}$ & 15 & 15 & 10 \\
\hline 7. $\quad$ Private law (40) & 20 & 10 & 5 \\
\hline 8. & Criminal law (45) & 25 & 10 & 10 \\
\hline
\end{tabular}

Table 3: The types of legal task texts

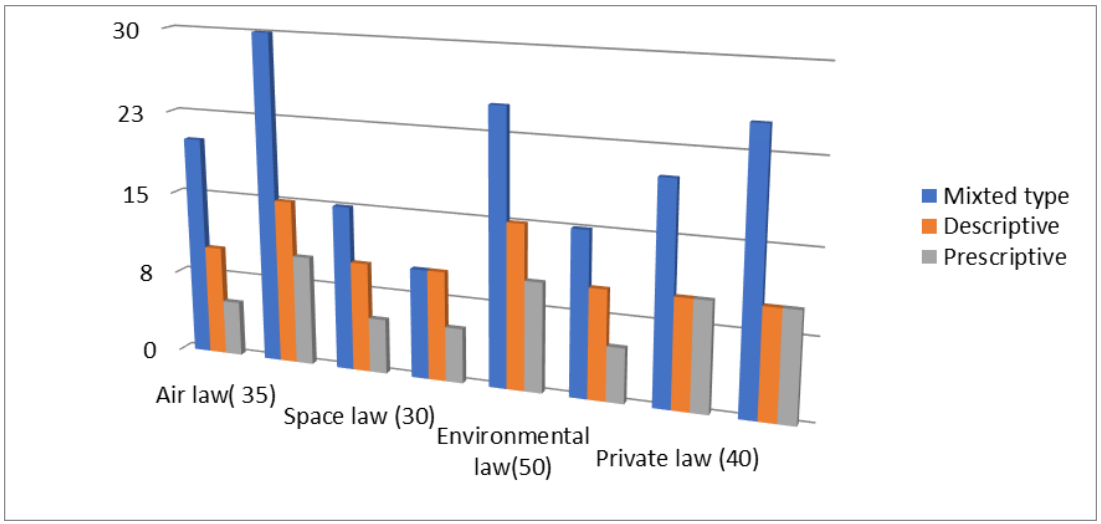

Figure 3: The types of legal task texts

From table 3 we may conclude that mixed types of legal tasks, based on descriptive and prescriptive texts, are the most common. The texts of this type of legal tasks include the elements of normative and doctrinal texts, as well as judicial acts (decisions, lawsuits, orders)

The results of the linguistic analysis of legal tasks texts are presented in table 4 .

\begin{tabular}{|l|l|l|l|l|l|}
\hline Branch of law & Terms & $\begin{array}{l}\text { Cliché and } \\
\text { fixed } \\
\text { phrases }\end{array}$ & $\begin{array}{l}\text { Impersonal } \\
\text { constructions }\end{array}$ & $\begin{array}{l}\text { Passive } \\
\text { voice }\end{array}$ & $\begin{array}{l}\text { Emotionally } \\
\text { colored } \\
\text { lexical units }\end{array}$ \\
\hline Air law & 23 & 27 & 19 & 21 & 10 \\
\hline $\begin{array}{l}\text { The law of the } \\
\text { sea }\end{array}$ & 20 & 20 & 30 & 20 & 5 \\
\hline Space law & 26 & 24 & 25 & 15 & 10 \\
\hline Economic law & 27 & 20 & 35 & 13 & 5 \\
\hline $\begin{array}{l}\text { Environmental } \\
\text { law }\end{array}$ & 20 & 18 & 20 & 27 & 15 \\
\hline
\end{tabular}

XLinguae, Volume 13 Issue 2, April 2020, ISSN 1337-8384, ISSN 2453-711X 


\begin{tabular}{|l|l|l|l|l|l|}
\hline $\begin{array}{l}\text { Commercial } \\
\text { law }\end{array}$ & 25 & 30 & 20 & 20 & 5 \\
\hline Private Law & 35 & 20 & 20 & 20 & 5 \\
\hline Criminal law & 30 & 20 & 15 & 20 & 15 \\
\hline
\end{tabular}

Table 4

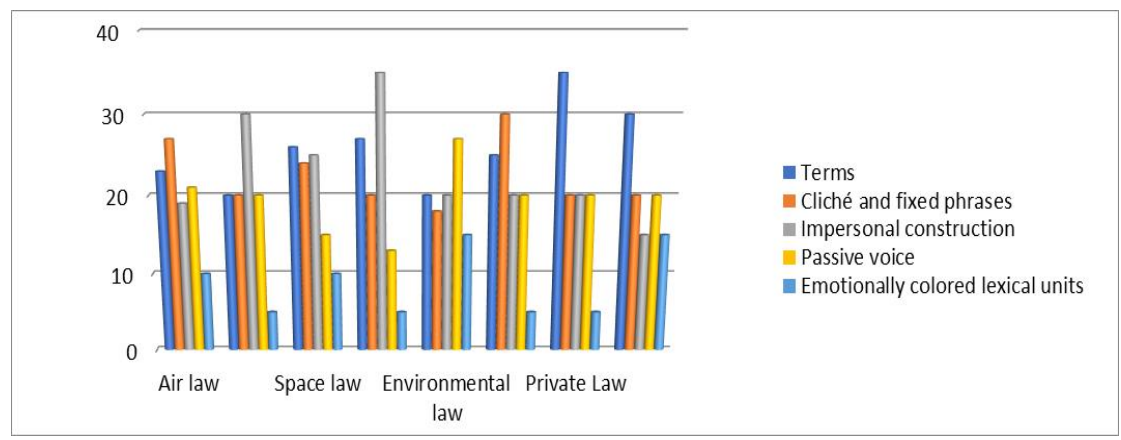

\section{Figure 4: Linguistic analysis of legal tasks texts}

The analysis has shown that the main linguistic and stylistic peculiarities of the texts of legal tasks, unlike other types of legal texts, are emotionally colored lexical units, exclamatory sentences, interjections.

E.g:

Le 12avril 2017, le vol régulier 'VVV1576 de BonbonAirline a décollé de Bonbon et s'est dirigé calmement vers l'est le long de la voie aérienne 911. En passant audessus de la fameuse réserve naturelle Crocodile, il a été abbattu par un missile, ce qui a provoqué un écrasement inévitable de l'avion, faisant 89 morts à bord. Peu de temps après, un message est apparu brièvement sur le compte de médias sociaux dece bandit Alfonco Draconien disant: «Je les ai eus !!!» accompagné d'une photo de la silhouette d'un homme tenant un lance-missiles.(calmement-bandit)

Another example is taken from an environmental law task:

Le Royaume de White Wave demande à la Cour de satisfaire le procès contre la République de Frozen Heart, avec laquelle elle a malheureusement des frontières maritimes communes, dans le cas de l'extermination brutale d'hippocampes dans la zone de son plateau continental, en raison de l'empoisonnement des eaux de l'océan Rose par les déchets de vilains navires du Frozen Heart, qui sont contrôlés par des personnes sans cervelle ni âme.

Such linguistic phenomena, unacceptable in normative legal texts and court decisions, play an important role in the training of young professionals due to an emotional coloring, making the learning process more effective and memorable. Emotions in law are permissible in some legal contexts. For example, when we imply civil proceeding, the speech of a lawyer or prosecution.

One of the main goals of educational legal tasks, in addition to creating the international lawyers' professional competences, is also the in-depth study of the legal (French) language, which often differs from the common one in terms of its special 
language means and structure. The skills such as translation, correct use of legal terms of a particular area of the international law, the preparation of documents are acquired faster via working with a legal task.

A thorough analysis of the texts of legal tasks from the position of their linguistic content allows structuring the lexical material - terms, clichés, phraseological units with the aim of creating new similar texts.

\section{Conclusions}

The authors of the research have managed to carry out a holistic grammatical, lexical, and syntactic analysis of the texts of legal tasks, to reveal the peculiarities of the text structure and to establish the basic principles of creating the text of the legal task in the French language.

The linguistic analysis of the texts of legal tasks as a special typological variety of legal texts has shown the following. The texts of legal tasks have a specific text structure, combining the elements of both normative (treaties, conventions, pacts) and procedural documents (court decisions, lawsuits). A linguistic study of the texts of legal tasks has revealed the interaction between their grammatical and semantic features.

Possessing all the necessary characteristics of a legal text, such as coherence and consistency, accuracy, clarity and conciseness, legal task texts also include the expressive elements which are not characteristic of other types of legal texts. We can say that the text of the legal task has been considered from the point of its semantic, grammatical and stylistic unity, in which the interaction and mutual influence of semantic, grammatical and lexical factors create a new style of legal texts in the context of its educational focus, aimed at forming the professional competences of international lawyers.

The scientific and practical significance of the research and its results lies in the creation of principles for carrying out the functional linguistic analysis of legal texts, and of recommendations for creating legal documents and didactic materials in the training of future international lawyers.

\section{Bibliographic references}

ADMIRAAL, W. - WUBBELS, T. - PILOT, A. 1999. Research in Higher Education 40: 687.https://doi.org/10.1023/A:1018712914619

ALWAZNA, R. 2018. Translation and legal terminology: Techniques for coping with the untranslatability of legal terms between Arabic and English. International Journal for the Semiotics of Law. https://doi.org/10.1007/s11196-018-9580-y.

AUER, A. - BERTELOOT, P. - MIELKE, B. - SCHIKORA, C. - SCHMIDT, T. WOLFF, C. 2019. Stylometry in legal linguistics: Use of corpus-linguistic methods for the analysis of german-language decisions. [Nutzung korpuslinguistischer Verfahren für die Analyse deutschsprachiger Urteile] Jusletter IT, (February) Available online: www.scopus.com

BRATTSEVA, E. F. - KOVALEV, P. 2015. The power of case study method in developing academic skills in teaching Business English (time to play)//Liberal Arts in Russia, vol. 4, n. 3, pp. 234-242. DOI: 10.15643/libartrus-2015.3.7

BUSSE, D. 1991. Juristische Fachsprache und Öffentlicher Sprachgebrauch. In: Liedtke F., Wengeler M., Böke K. (Eds.) Begriffe besetzen. VS Verlag für Sozialwissenschaften. DOI https://doi.org/10.1007/978-3-322-92242-7_10

BUSSE, D. 1992a. Der Bedeutungswandel des Begriffs "Gewalt" im Strafrecht. Über institutionell-pragmatische Faktoren semantischen Wandels. In: Dietrich Busse (Hrsg.): Diachrone Semantik und Pragmatik. Untersuchungen zur Erklärung und Beschreibung des Sprachwandels. (= Reihe Germanistische Linguistik, Bd. 113) Tübingen: Niemeyer, 1991, pp. 259-275. [Busse-1991-04]

XLinguae, Volume 13 Issue 2, April 2020, ISSN 1337-8384, ISSN 2453-711X 
BUSSE, D. 1992b. Recht als Text. Linguistische Untersuchungen zur Arbeit mit Sprache in einer gesellschaftlichen Institution. Tübingen: Max Niemeyer Verlag, p. 366 (Reihe Germanistische Linguistik Bd. 131)

BUSSE, D. 1993. Juristische Semantik. Grundfragen der juristischen Interpretationstheorie in sprachwissenschaftlicher Sicht. Berlin: Duncker \& Humblot, p. 318. (2. Auflage 2010)

BUSSE, D. 2000a. Textsorten des Bereichs Rechtswesen und Justiz. In: Gerd Antos/Klaus Brinker/Wolfgang Heinemann et al. (Hg.): Text- und Gesprächslinguistik.

BUSSE, D. 2000b. Textlinguistik und Rechtswissenschaft. In: Gerd Antos/Klaus Brinker/Wolfgang Heinemann et al. (Hg.): Text- und Gesprächslinguistik. Ein internationales Handbuch zeitgenössischer Forschung. 1. Halbband (Handbücher zur Sprach - und Kommunikationswissenschaft. Bd. 16.1). Berlin/New York, pp. 803811.

BUSSE, D. 2005. Ist die Anwendung von Rechtstexten ein Fall von Kommunikation? Rechtslinguistische Überlegungen zur Institutionalität der Arbeit mit Texten im Recht.

In: Kent Lerch (Hrsg.): Die Sprache des Rechts. Band 2: Recht vermitteln. Strukturen, Formen und Medien der Kommunikation im Recht. Berlin / New York: de Gruyter, pp. 23-53. [Busse-2005-04]

BUSSE, D. 2018a. Michaela Felden/Detmer Wulf: Bedeutungs- und Begriffswissen im Recht: Frame-Analyse von Rechtsbegriffen im Deutschen. (= Reihe Sprache und Wissen Bd. 34) Berlin/Boston: de Gruyter, p. 382.

BUSSE, D. 2018b. Sprache und Recht. In: Liedtke F., Tuchen A. (Eds) Handbuch Pragmatik. J. B. Metzler, Stuttgart. DOI https://doi.org/10.1007/978-3-476-046246_37

BUSSE, D. 2019. Sprache und Recht. In: Frank Liedtke/Astrid Tuchen (Hrsg.): Handbuch Pragmatik. Stuttgart: Metzler, pp. 383-393.

CAKMAK, Z. - AKGÜN, I. 2017. A Theoretical Perspective on the Case Study Method. Journal of Education and Learning. 7. 96. 10.5539/jel.v7n1p96.

CHARROW, V. R. - CRANDALL, J. A. - CHARROW, R. P. 1982. Characteristics and functions of legal language. In: R. Kittredge \& J. Lehrberger (Eds.), Sublanguage: Studies of language in restricted semantic domains (pp. 175-190). Berlin: Walter de Gruyter. Criminal Justice Newsletter. July 1, 1985. Problems cited in greater use of court interpreters, vol. 16, n. 13.

ENGBERG, J. 1993. Prinzipien einer Typologisierung juristischer Texte. In: Fachsprache 1/2, pp. 31-38.

ERIKSEN, L. 1999. Einfuhrung in die Systematik der juristischen Fachsprache//Juristische Fachsprache. Kongressberichte des 12-th European Symposium on Language for Special Purposes; hrsg. L.Eriksen, K. Luttermann. Bruxelles, Bressanone, Munster: LIT Verlag, 2002, pp. 1-19.

GARVIN, D. A. 2003. "Making the Case: Professional Education for the World of Practice." Harvard Magazine (September-October 2003), pp. 56-65; 107.

GIZBERT-STUDNICKI, T. 1986. Jezykprawny z perspektyw y socjolingwistycznej In: Zeszyty Naukowe Universytetu Jagiellonskiego. DCCL XXVII. Prace z naukpolitycznych. Zeszyt 26. Warszawa, Krakow: PWN, p. 139.

IRKOVA, A. 2019. Prejuridical and juridical meanings of a lexeme "grazhdanin" (a citizen) in social-political discourse. Sibirskiy filologicheskiy zhurnal, pp. 215-224. Doi: $10.17223 / 18137083 / 68 / 19$.

JOHANSEN, L. V. 2018. Using legal language as a non-lawyer: Danish lay judges' linguistic strategies during criminal trials. Nordic Journal of Linguistics, vol. 41, n. 2, pp. 227-246. https://doi.org/10.1017/S0332586518000124 
LEUNG, E. - JOHN, G. 2009. Interpreting Cantonese utterance particles in bilingual courtroom discourse. Interpreting, vol. 11, n. 2, pp. 190-215. DOI: 10.1075/intp.11.2.05leu

LEVI, J. N. 1990 The Study of Language in the Judicial Process. In: Levi J. N., Walker A. G. (Eds.) Language in the Judicial Process. Law, Society and Policy, vol 5. Springer, Boston, MA DOI: https://doi.org/10.1007/978-1-4899-3719-3_1

MOSKOVITZ, M. 1992. Beyond the Case Method: It's Time to Teach with Problems. Journal of Legal Education, vol. 42, n. 2, pp. 241-270. Available online: http://www.jstor.org/stable/42893216

OTTO, W. 1981. Die Paradoxie einer Fachsprache In: Deroffentliche Sprachgebrauch. Band. II. Stuttgart: Klett-Cotta, pp. 44-57.

PHILIPPA, R. 2017. Teaching collaborative problem-solving skills to law students, The Law Teacher, vol. 51, n. 2, pp. 138-150, DOI: 10.1080/03069400.2015.1111580

PRIETO RAMOS, FERNANDO. 2011. Developing Legal Translation Competence: An Integrative Process-Oriented Approach. In: Comparative Legilinguistics International Journal for Legal Communication, vol. 5, pp. 7-21. Available online: https://archive-ouverte.unige.ch/unige: 16166

SALA, M. 2019. Interrogative engagement as a pragmatic and textual function in legal studies Pragmatics and Beyond. New Series, 301, pp. 101-117, DOI: 10.1075/pbns.301.06sal , Available online: www.scopus.com

SARCEVIC, S. 1997. New approach to legal translation. Den Haag: Kluwer, P. 282.

VOGEL, F. - HAMANN, H. - GAUER, I. 2018. Computer-Assisted Legal Linguistics: Corpus Analysis as a New Tool for Legal Studies. doi:10.3233/978-161499-726-9-195

YAO, L. - GE, J. - LI, C. - YAO, Y. - LI, Z. - ZENG, J. - CHANG, V. 2019. Word Segmentation for Chinese Judicial Documents. In X. Cheng, W. Jing, X. Song, \& Z. Lu (Eds.), Data Science - 5th International Conference of Pioneering Computer Scientists, Engineers and Educators, ICPCSEE, Proceedings pp. 466-478. (Communications in Computer and Information Science; Vol. 1058). Springer-Verlag. https://doi.org/10.1007/978-981-15-0118-0_36

ZHALINSKIJ, A. E. 2009. Vvedenie v speciallnost "YUrisprudenciya". Professional' nayadeyatellnostt yurista: ucheb. - 2-eizd., pererab. idop. - "Prospekt", 362 p.

Words: 6287

Characters: 40 925(22,74 standard pages)

Ivan I. Sinyakin, Phd

Assistant Professor

International Law Department

Moscow State Institute of International Relations

(MGIMO University)

119454, Moscow, ProspektVernadskogo, 76

Russia

ORCID: 0000-0002-8899-4219

ilc48@mail.ru

Ekaterina A. Samorodova, Phd

Assistant Professor

French Language Department

Moscow State Institute of International Relations

(MGIMO University)

119454, Moscow, ProspektVernadskogo, 76

Russia

XLinguae, Volume 13 Issue 2, April 2020, ISSN 1337-8384, ISSN 2453-711X 
ORCID : https ://orcid.org/0000-0002-0702-0253

samorodova.ekaterina.78@mail.ru

Irina G. Belyaeva, Phd

Senior Lecturer

German Language Department

Moscow State Institute of International Relations

(MGIMO University)

119454, Moscow, ProspektVernadskogo, 76

Russia

ORCID : https ://orcid.org/0000-0002-7083-3564

irinatimakova@mail.ru 